\title{
Analisis Reduksi Debit Banjir Di Dalam DAS Pucang Gading
}

\author{
Nicko Fadhil Muhammad ${ }^{1}$, Suseno Darsono ${ }^{2}$, Suharyanto $^{3}$, Agus Supriyanto ${ }^{4}$ \\ Mahasiswa Program Magister Teknik Sipil, Fakultas Teknik, Universitas Diponegoro ${ }^{1}$ \\ Teknik Sipil, Fakultas Teknik, Universitas Diponegoro ${ }^{2}$ \\ Teknik Sipil, Fakultas Teknik, Universitas 17 Agustus 1945 Semarang \\ Email: nickofadhil90@gmail.com ${ }^{1}$, sdarsono@ hotmail.com² ${ }^{2}$, suharyanto20@yahoo.co.id ${ }^{2}$, agus- \\ supriyanto@untagsmg.ac.id ${ }^{3}$ \\ DOI: http://dx.doi.org/10.31869/rtj.v4i2.2344
}

\begin{abstract}
Abstrak: Pemerintah Indonesia menyusun kebijakan Nasional Sumber Daya Air. Undang-undang Nomor. 17 Tahun 2019 tentang Sumber Daya Air (SDA) dimaksudkan untuk mengelola SDA wilayah sungai, baik jangka pendek, menengah maupun jangka panjang secara berkelanjutan. Bencana banjir di DAS Pucang Gading terjadi di beberapa tahun terakhir. Banjir pada wilayah tersebut berakibat buruk bagi lingkungan sekitar. Kerugian tidak hanya dialami oleh masyarakat namun juga oleh pemerintah di daerah tersebut. Penelitian ini bertujuan untuk mereduksi banjir di DAS Pucang Gadingagar menjadi referensi dalam menanggulangi banjir yang terjadi di wilayah tersebut. Beberapa analisis yang dilakukan adalah menganalisis banjir kondisi eksisting dengan debit banjir kala ulang 100 tahun (skema 1), analisis untukmereduksi banjir dengan penambahan embung dan kolam rencana (skema 2), analisis untuk mereduksi banjir dengan penambahan embung, kolam dan sudetan rencana (skema 3), serta memilih alternatif pemodelanyang sesuai pada lokasi banjir. Berdasar pada hasil analisis, alternatif yang direkomendasikan untuk berbagai lokasi banjir adalah sebagai berikut: lokasi banjir Perumahan Dinar Indah direkomendasikan 5 Embung (Kayen, Panggang Timur, Panggang, Mluweh dan Kalongan) yangmereduksi sebesar $84,20 \mathrm{~m}^{3} /$ detik $(13,79 \%)$, lokasi banjir jalan raya depan Kubota direkomendasikan Sudetan 1 yang mereduksi sebesar 9,60 $\mathrm{m}^{3} /$ detik $(80 \%)$, lokasi banjir Taman Tirto Agung direkomendasikan Sudetan 1 dan Kolam Tirto Agungyang mereduksi sebesar 31,40 $\mathrm{m}^{3} /$ detik $(58,26 \%)$, lokasi banjir Jl. Durian direkomendasikan Kolam KORPRI yang mereduksi sebesar $3,10 \mathrm{~m}^{3} /$ detik $(48,44 \%)$, lokasi banjir simpang UNPAND direkomendasikan 5 Kolam (Tirto Agung, Graha Estetika, Tirto Husodo, UNPAND dan KORPRI) dan 2 sudetan yang mereduksi sebesar $44,80 \mathrm{~m}^{3} /$ detik $(57,36 \%)$ dan $45,20 \mathrm{~m}^{3} /$ detik $(40,21 \%)$, lokasi Bendung Pucang Gading direkomendasikan 8 embung dan 5 kolam yang mereduksi sebesar $61,60 \mathrm{~m}^{3} /$ detik $(11,28 \%)$.
\end{abstract}

Kata kunci: Reduksi, Debit Banjir, Embung, Kolam, Sudetan, DAS Pucang Gading.

\section{PENDAHULUAN \\ Latar Belakang}

Pemerintah Indonesia menyusun

kebijakan Nasional Sumber Daya Air. Undang-undang Nomor. 17 Tahun 2019 tentang Sumber Daya Air (SDA) dimaksudkan untuk mengelola SDA wilayah sungai, baik jangka pendek, menengah maupun jangka panjang secara berkelanjutan. Untuk memenuhi kebutuhan air di berbagai sektor, maka perlu dirumuskankan arahan pengelolaan sumber daya air terpadu sebagai pijakan dalam kegiatan pengelolaan sumber daya air yang selaras, serasi, seimbang, berwawasan lingkungan dan berkesinambungan. Pengelolaan sumber daya air yang tercantum pada UU Nomor. 17 Tahun 2019 berdasarkan asas :

- Kemanfaatan umum.

- Keterjangkauan.
- Keadilan.

- Keseimbangan.

- Kearifan lokal.

- Wawasan lingkungan.

- Kelesatarian.

- Keberlanjutan.

- Keterpaduan dan keserasian.

- Transparansi dan akuntabilitas.

Pada proses pengendalian banjir, terdapat dua hal yang bisa dilakukan yaitu dengan menggunakan metode struktur dan non struktur. Penanggulangan banjir dengan metode struktur adalah dengan membangun atau menciptakan bangunan pengendali banjir, sementara metode non struktur adalah dengan melakukan pengelolaan dan penataan daerah yang berpotensi banjir. Beberapa metode struktur diantaranya adalah dengan bendungan, kolam penampungan, tanggul penahan banjir, saluran by pass, normalisasi 
sungai dan sistem drainase khusus (Yudi, et al. 2017).

DAS Pucang Gading memiliki 2 sub DAS yaitu subDAS Gede yang hulunya berada di Kabupaten Semarang dan subDAS Krengseng yang hulunya berada di Kota Semarang. Aliran 2 sungai tersebut bertemu di Kecamatan Tembalang mengalir hingga ke Bendung Pucang Gading yang selanjutnya melalui Bendung Pucang Gading alirannya dibagi menjadi 3 aliran sungai yaitu Kanal Banjir Timur, Dombo Sayung dan Babon.
Beberapa area didalam DAS Pucang Gading yang berada di wilayah administrasi Kota Semarang sering kali terjadi banjir. Banjir tersebut terjadi di Kecamatan Banyumanik dan Tembalang. Peta lokasi banjir DAS Pucang Gading digambarkan pada Gambar 1. Akibat dari banjir tersebut adalah tergenangnya jalan dan pemukiman padat penduduk. Banjir pada wilayah tersebut berakibat buruk bagi perekonomian, sosial dan lingkungan sekitar. Kerugian tidak hanya dialami oleh masyarakat namun juga oleh pemerintah setempat di daerah tersebut.

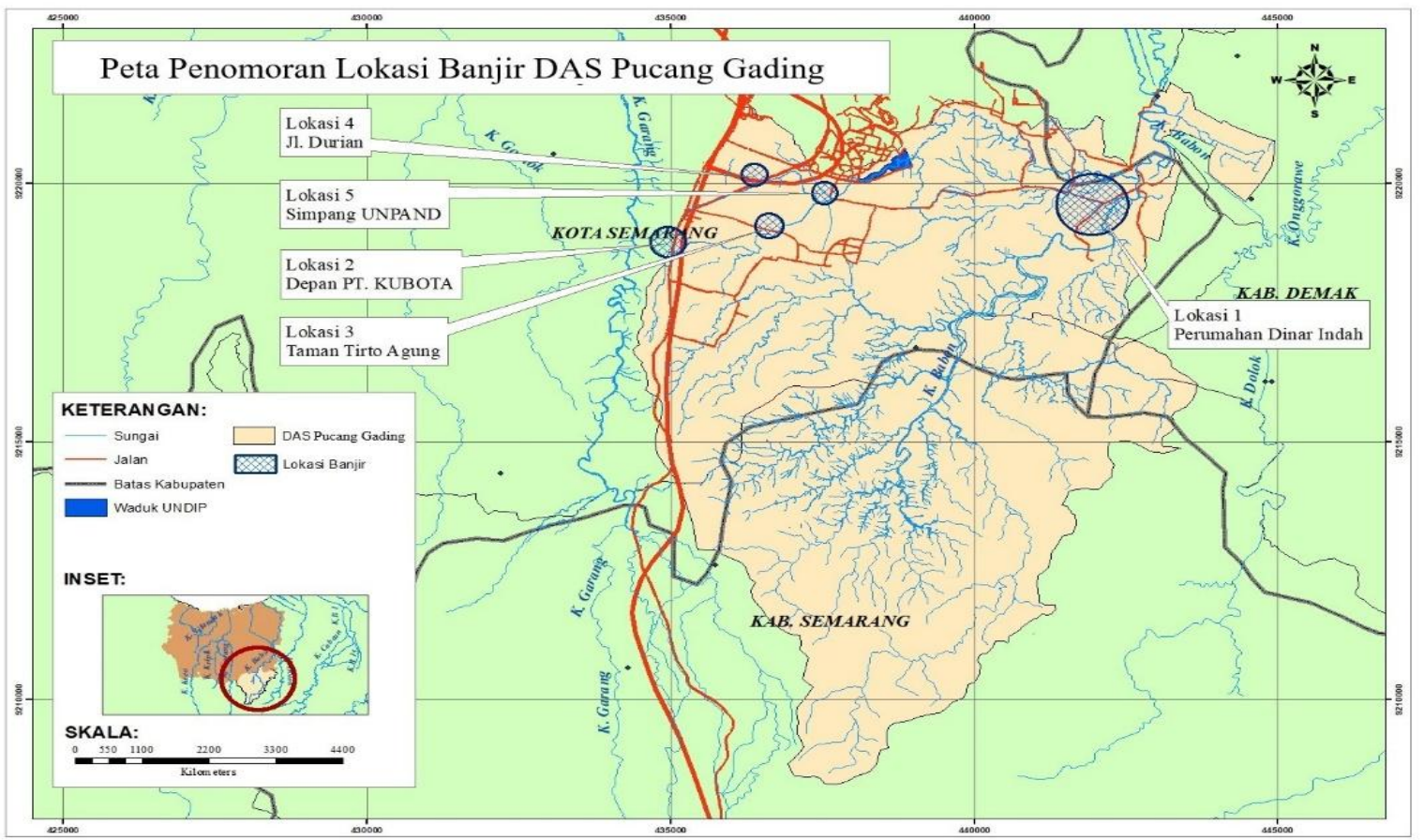

Gambar 1. Peta banjir DAS Pucang Gading (Sumber: CV. Mitra Muda Rekayasa, 2019).

Penelitian reduksi banjir di DAS Pucang Gading adalah hal penting yang harus dilakukan agar menjadi referensi dalam menanggulangi banjir yang terjadi di wilayah tersebut.

\section{Rumusan Masalah}

Banjir yang terjadi di DAS Pucang Gading disebabkan oleh tingginya debit banjir sehingga mengakibatkan meluapnya sungaisungai yang ada di DAS Pucang Gading. Permasalahan ini dapat dirumuskan sebagai berikut :

1. Berapa besar debit banjir potesial yang terjadi.

2. Bagaimana skemayang dapat mereduksi debit banjir puncak yang paling maksimal untuk menanggulangi banjir di area tersebut.

\section{Maksud dan Tujuan Penelitian}

Maksud penelitian ini adalah untuk menganalisis reduksi debit banjir puncak untuk menanggulangi debit banjir di DAS Pucang Gading menggunakan software HECHMS.

Tujuan dari penelitian ini adalah memilih alternatif pemodelan yang dapat mereduksi debit banjir yang sesuai dengan masing-masing lokasi banjir.

\section{METODOLOGI PENELITIAN}

Dalam penelitian diperlukan analisis dan tahapan-tahapan yang akan dilakukan untuk mengurangi kesalahan dalam sebuah penelitian dan diharapkan dapat mencapai hasil yang maksimal dalam menganalisis 
penelitian. Analisis yang dilakukan pada penelitian ini adalah sebagai berikut:

1. Melakukan analisis banjir dengan kondisi eksisting, selanjutnya disebut skema 1.

2. Melakukan analisis banjir dengan menggunakan penambahan 5 embung rencana di Sungai Pucang Gading, 3 embung dan 5 kolam rencana di Sungai Krengseng, selanjutnya disebut skema 2.

3. Melakukan analisis banjir dengan menggunakan penambahan 5 embung rencana di Sungai Pucang Gading, 3 embung, 5 kolam rencana di Sungai Krengseng dan 2 sudetan di sungai Krengseng. Sudetan pertama menyudet Sungai Krengseng dialirkan menuju ke Sungai Garang yang berfungsi membagi debit banjir ke Sungai Garang dan ke Sungai Krengseng eksisting. Sudetan kedua membagi debit banjir dari kolam rencana Tirto Agung aliran dibagi 2 yaitu menuju Sungai Krengseng Eksisting dan menuju kolam rencana Graha Estetika kemudian dibagi lagi menuju Sungai Gede dan Sungai Krengseng eksisting, selanjutnya disebut skema 3 .

\section{Pengolahan Data Hidrologi}

Pengolahan data dilakukan melalui 3 tahapan yaitu:

a. Perhitungan curah hujan rerata tahunan

Data hujan diambil dari 3 stasiun hujan yang berada di DAS Pucang Gading yaitu: Stasiun Hujan Banyumeneng, Gunungpati dan Pucang Gading. Data hujan yang digunakan pada penelitian ini adalah data curah hujan harian dari 3 staiun hujan tahun 2001 sampai dengan 2019. Ada penelitian ini analisis data curah hujan dengan menggunakan rerata thiessen.

b. Analisis distribusi

Analisis distribusi hujan menggunakan metode Normal, Gumbel, Log Pearson III dan Log Normal.

c. Uji distribusi

Pengujian distribusi dilakukan menggunakan Chi-Kuadrat dan Smirnov Kolmogorov.

Tahapan analisis dan uji distribusi dilakukan menggunakan software Aprob.

\section{Penelusuran Banjir}

Penelusuran banjir adalah suatu metode yang dilakukan unutk menentukan waktu dan debit aliran (hidrogaf) di suatu titik aliran berdasarkan hidrograf di suatu titik aliran berdasarkan hidrograf yang diketahui sebelah hulu (Triatmodjo, 2009)

Penelusuran banjir dilakukan menggunakan software HEC-HMS.

\section{Metode Pengumpulan Data}

1. Data Hidrologi

Data hidrologi yang digunakan adalah:

a. Data DAS Pucang Gading.

Data DAS tersebut diambil dari CV. Mitra Muda Rekayasa, data yang digunakan adalah luas DAS, panjang sungai utama dan peta kontur DAS.

b. Data curah hujan.

Data ini merupakan data sekunder yang diambil dari PUSDATARU Provinsi Jawa Tengah. Data curah hujan yang diambil dari 3 stasiun yang berdekatan dengan DAS Pucang Gading yaitu Stasiun Hujan Banyumeneng, Stasiun Hujan Gunungpati dan Stasiun Hujan Pucang Gading.

2. Data Embung

Data embung rencana dan eksisting di DAS Pucang Gading diperoleh dari CV. Mitra Muda Rekayasa yang berjumlah 8 embung, 5 kolam dan 2 sudetan rencana. Lokasi embung, kolam dan sudetan rencana ditampilkan pada Gambar 2. Data rekap kapasitas dan luas genangan embung dan kolam ditampilkan pada Tabel 1, sedangkan data sudetan rencana ditampilkan pada Tabel 2. 


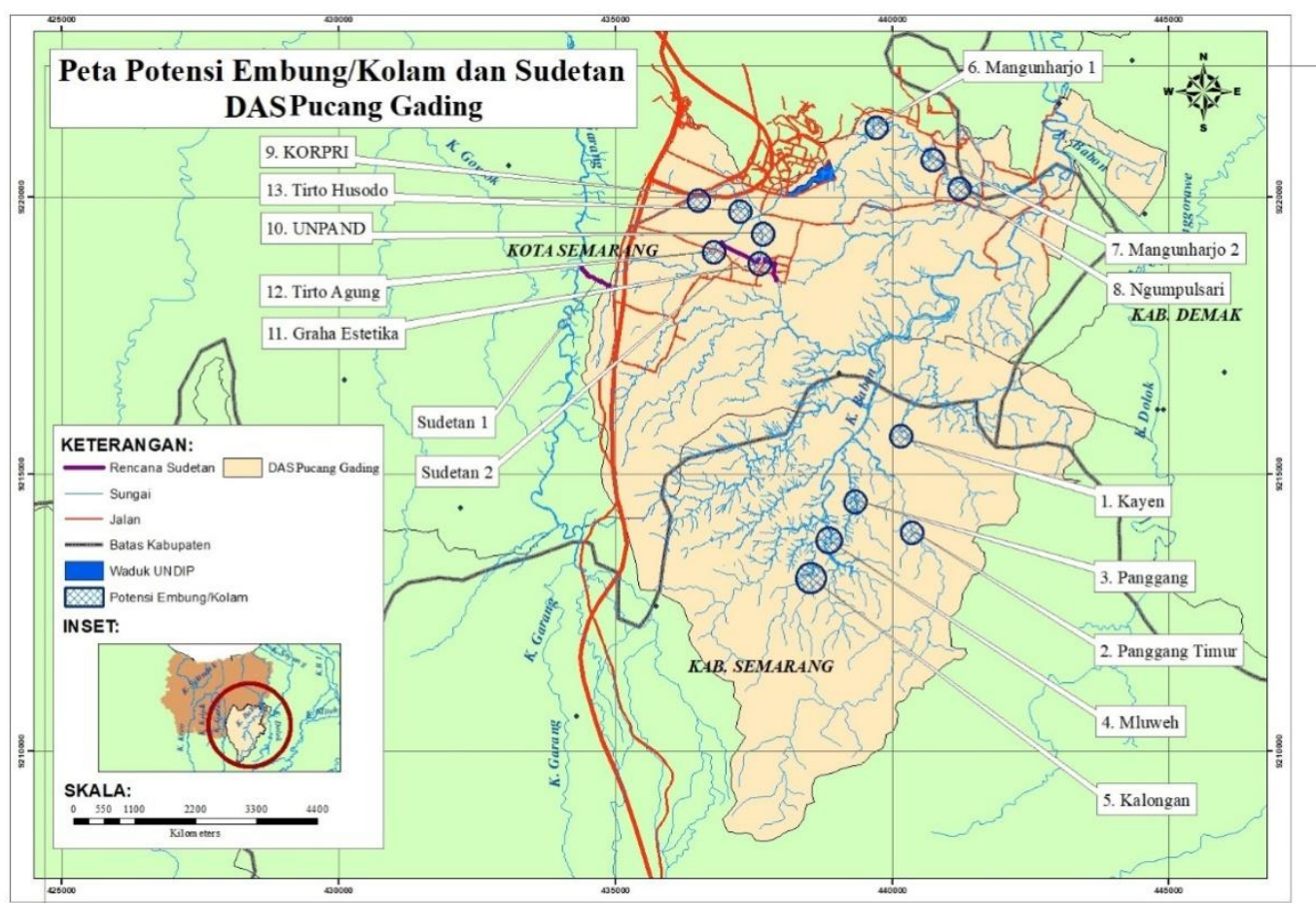

Gambar 2. Peta embung, kolam dan sudetan rencana (Sumber: CV. Mitra Muda Rekayasa, 2019).

Tabel 1. Daftar rekap embung dan kolam rencana.

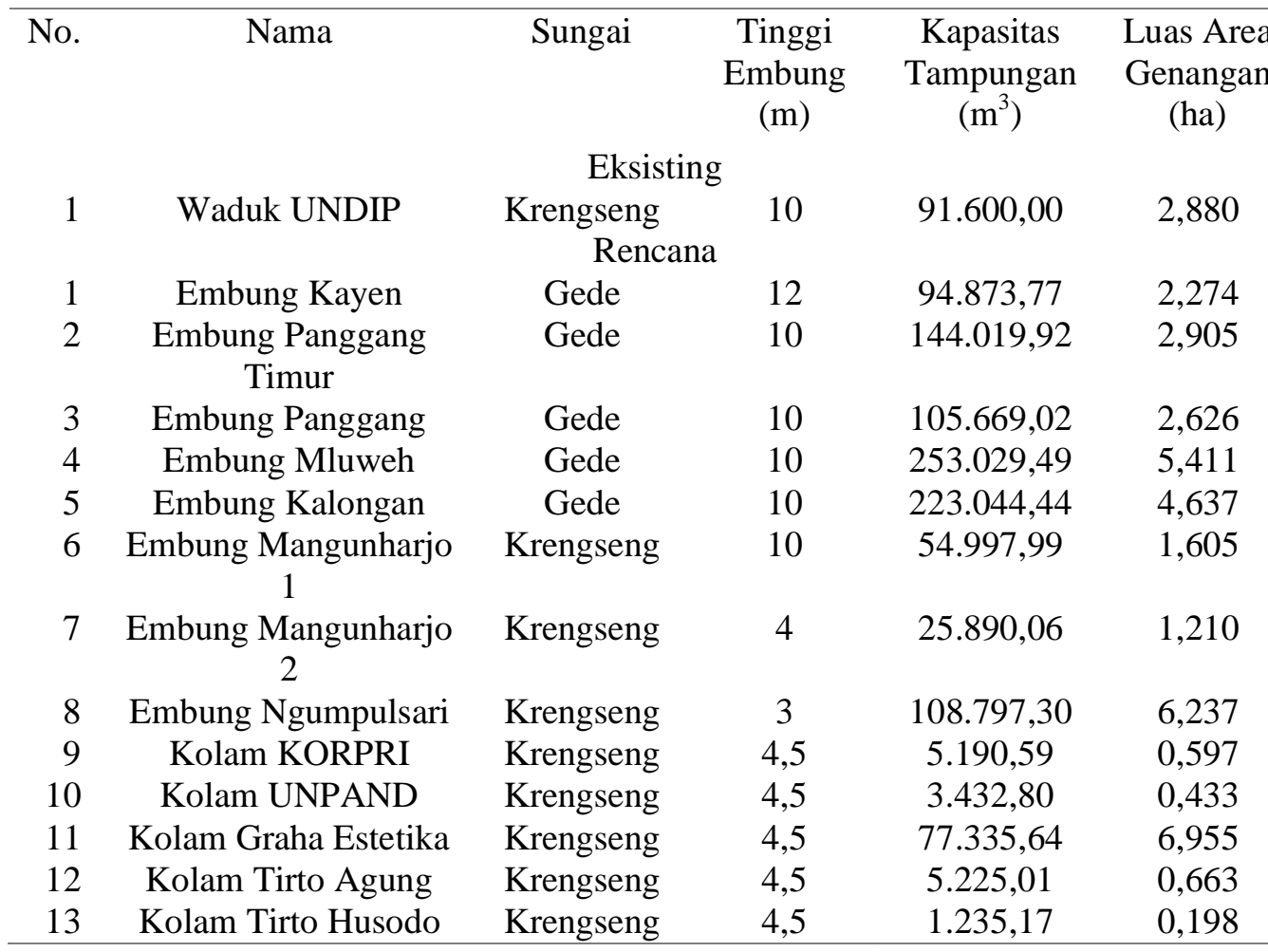

(Sumber: CV. Mitra Muda Rekayasa, 2019).

Tabel 2. Daftar rekap sudetan rencana.

\begin{tabular}{|c|c|c|c|c|}
\hline $\begin{array}{c}\text { No } \\
\text {. }\end{array}$ & Nama Sudetan & $\begin{array}{c}\text { Sungai } \\
\text { Asal }\end{array}$ & Sungai Tujuan & $\begin{array}{l}\text { Panjang } \\
\text { Sudetan } \\
\text { (m) }\end{array}$ \\
\hline
\end{tabular}


Vol. 4 No.2 Juni 2021

http://jurnal.umsb.ac.id/index.php/RANGTEKNIKJOURNAL

\begin{tabular}{ccccc}
\hline 1 & Sudetan Rencana & Krengsen & Garang & 674,028 \\
& 1 & $\mathrm{~g}$ & & \\
2 & Sudetan Rencana & Krengsen & Anak Sungai Gede & $1.911,451$ \\
& 2 & $\mathrm{~g}$ & & \\
\hline
\end{tabular}

\section{ANALISIS DAN PEMBAHASAN \\ Peta DAS}

Pada penelitian ini langkah pertama adalah dengan pembuatan peta DAS yang didalamnya terdapat sub DAS, alur sungai dan embung eksisting. Pembagian sub DAS pada DAS Pucang Gading yang menjadi pembahasan penelitian ini. dibagi menjadi 90 sub DAS.

\section{Analisis Curah Hujan}

Pada penelitian ini stasiun hujan yang digunakan adalah Stasiun hujan Gunungpati, Banyumeneng dan Pucang Gading. Data curah hujan harian yang digunakan dari stasiun-stasiun tersebut adalah 19 tahun yaitu 2001 sampai dengan
(Sumber: CV. Mitra Muda Rekayasa, 2019).

2019.Berdasarkan pembagian wilayah poligon Thiessen luas wilayah pengaruh stasiun hujan adalah sebagai berikut:

a. Stasiun hujan Gunungpati memiliki pengaruh seluas $33,95 \mathrm{~km}^{2}$ kemudian dibuat persentese menjadi 43,38\%.

b. Stasiun hujan Banyumeneng memiliki pengaruh seluas $23,73 \mathrm{~km}^{2}$ kemudian dibuat persentase menjadi 30,32\%.

c. Stasiun hujan Pucang Gading memiliki pengaruh seluas $20,58 \mathrm{~km}^{2}$ kemudian dibuat persentase menjadi $26,30 \%$.

Gambar pembagian wilayah poligon Thiessen ditampilkan pada Gambar 3 dan Perhitungan hujan maksimum ditampilkan pada Tabel 3

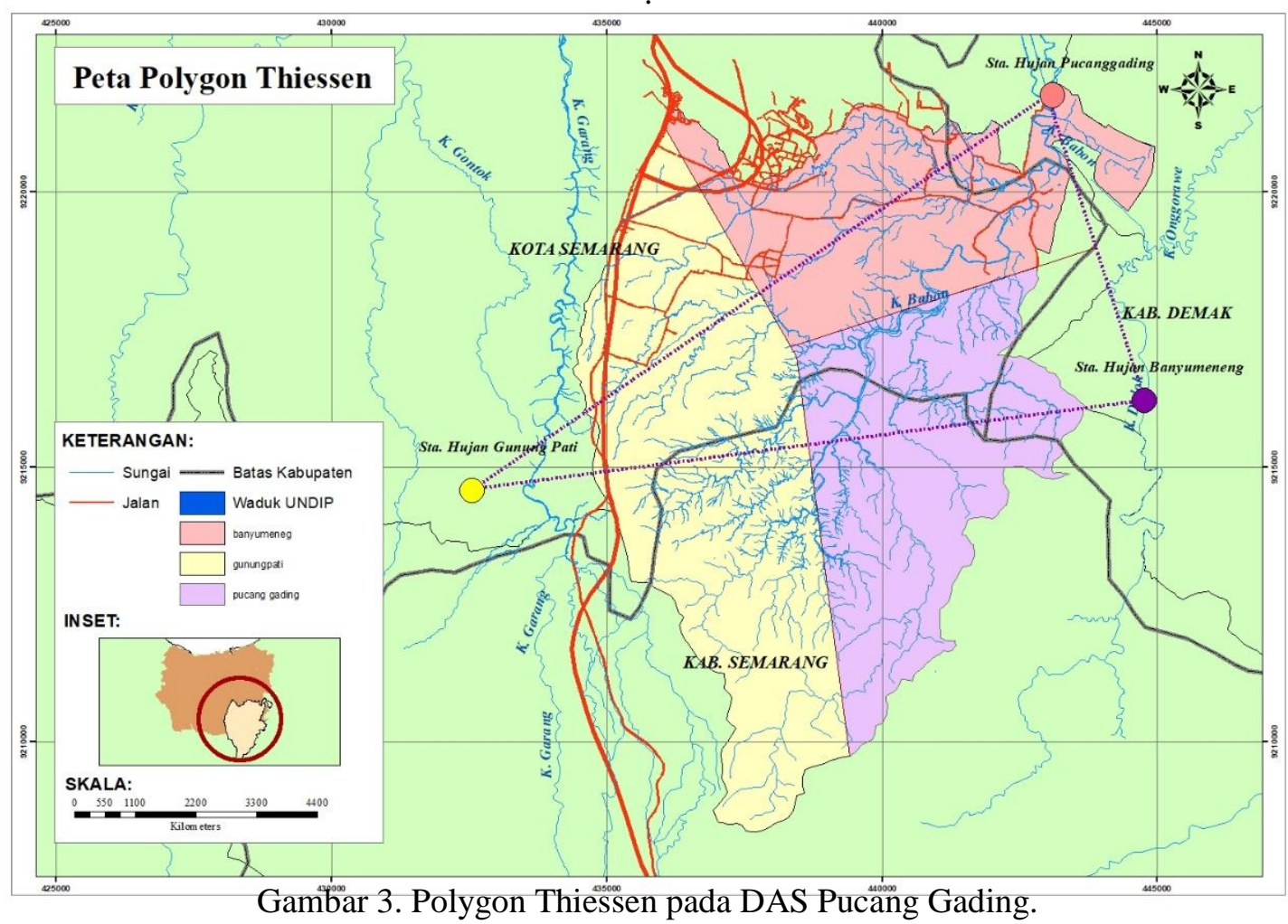

Tabel 3. Hasil perhitungan hujan DAS

\begin{tabular}{|c|c|}
\hline Tahun & Rmax (mm) \\
\hline 2001 & 49,853 \\
\hline 2002 & 66,220 \\
\hline 2003 & 72,178 \\
\hline
\end{tabular}

\begin{tabular}{|c|c|}
\hline 2004 & 72,889 \\
\hline 2005 & 52,507 \\
\hline 2006 & 88,633 \\
\hline 2007 & 177,432 \\
\hline 2008 & 106,073 \\
\hline
\end{tabular}


Vol. 4 No.2 Juni 2021

http://jurnal.umsb.ac.id/index.php/RANGTEKNIKJOURNAL

\begin{tabular}{|c|c|}
\hline 2009 & 94,332 \\
\hline 2010 & 80,070 \\
\hline 2011 & 99,971 \\
\hline 2012 & 60,881 \\
\hline 2013 & 79,904 \\
\hline 2014 & 83,106 \\
\hline 2015 & 90,374 \\
\hline 2016 & 116,732 \\
\hline 2017 & 57,511 \\
\hline 2018 & 46,687 \\
\hline
\end{tabular}

\section{$2019 \quad 56,397$}

Analisis Distribusi dan Penentuan Jenis Sebaran

Analisis dan uji distribusimenggunakan Aprob. Analisis menggunakan 4 metode yaitu metode Normal, Gumbel, Log Perason III dan Log Normal. Pemilihan distribusi dipilih dari nilai selisih maksimum terkecil. Setelah itu diuji menggunakan metode SmirnovKolmogorov dan Chi Kuadrat. Hasil Aprob ditampilkan pada Gambar 4.

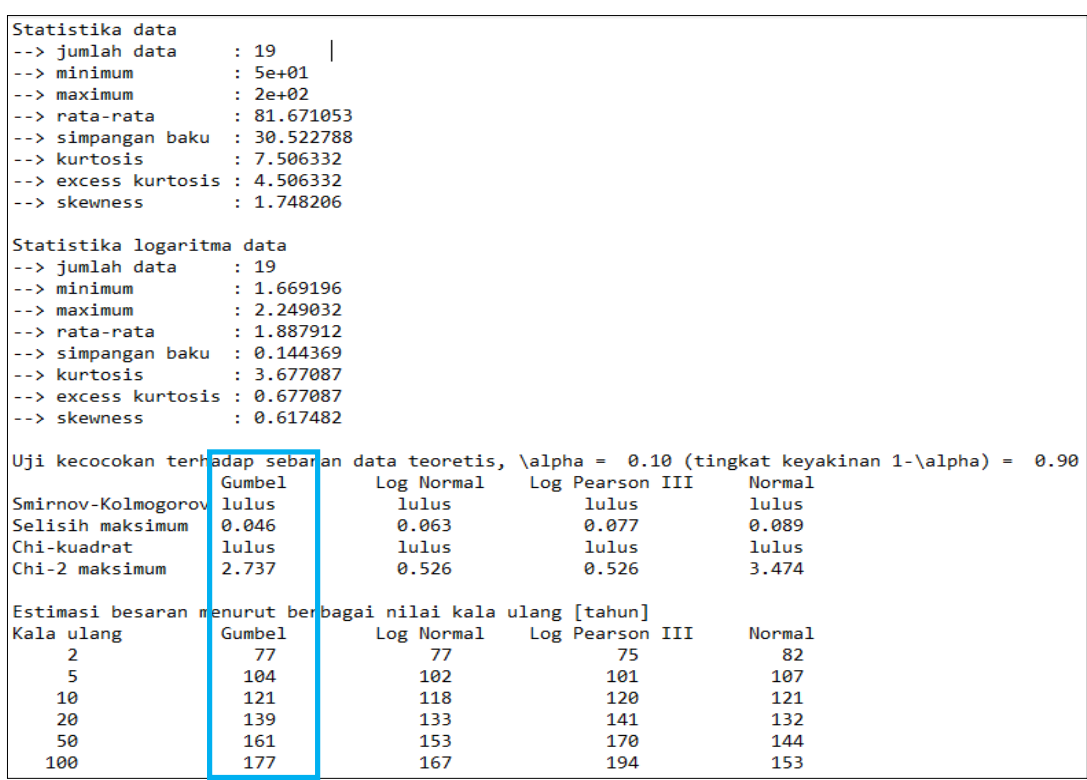

Gambar 4. Hasil analisis Aprob.

\section{Perhitungan Waktu Konsentrasi (TC)}

Waktu konsentrasi atau waktu tiba banjir adalah waktu yang diperlukan oleh air hujan untuk mengalirdari suatu titik yang paling jauh ke suatu titik tinjautertentu (Rachman, et al, 2014)

Pada penelitian ini waktu konsentrasi dihitung dari ujung hulu sungai Gede hingga Bendung Pucang Gading yang merupakan lokasi paling hilir. Hasil perhitungan TC ditampilkan pada Tabel 4. Pada perhitungan di Tabel 4 hasilnya adalah 4,10 jam sehingga dibulatkan menjadi 4 jam.
Perhitungan Curah Hujan Jam-jaman

Perhitungan curah hujan jam-jaman diperoleh dengan menggunakan kalibrasi distribusi hujan jam-jaman di DAS Pucang Gading, namun mengingat tidak diperolehnya data curah hujan jam-jaman yang berada di DAS Pucang Gading, maka diambil data dari stasiun hujan terdekat yaitu Stasiun Hujan Bandara Ahmad Yani sebagai pendekatan distribusinya. Hasil dari perhitungannya ditampilkan pada Tabel. 5 .

Tabel 4. Perhitungan waktu konsentrasi. 
Vol. 4 No.2 Juni 2021

http://jurnal.umsb.ac.id/index.php/RANGTEKNIKJOURNAL

\begin{tabular}{|c|c|c|c|c|c|c|c|c|}
\hline \multirow[t]{2}{*}{$\mathrm{No}$} & \multirow{2}{*}{$\begin{array}{l}\text { Nama } \\
\text { Subdas }\end{array}$} & \multirow{2}{*}{$\begin{array}{l}\text { Luas } \\
\mathrm{km}^{2}\end{array}$} & \multicolumn{2}{|c|}{ Panjang Sungai } & \multirow{2}{*}{$\begin{array}{l}\text { Elv. Hulu } \\
\text { (m) }\end{array}$} & \multirow{2}{*}{$\begin{array}{l}\text { Elv. Hilir } \\
\text { (m) }\end{array}$} & \multirow{2}{*}{$\begin{array}{c}\text { Kemiringan } \\
\text { (s) }\end{array}$} & \multirow{2}{*}{$\begin{array}{c}\mathrm{TC} \\
\text { (jam) }\end{array}$} \\
\hline & & & $(\mathrm{m})$ & $(\mathrm{Km})$ & & & & \\
\hline 1 & $\begin{array}{c}\text { SDG } \\
13\end{array}$ & 0,666 & $1.230,485$ & 1,230 & 144,000 & 48,000 & 0,08 & 0,21 \\
\hline 2 & $\begin{array}{c}\text { SDG } \\
14\end{array}$ & 7,553 & $10.760,649$ & 10,761 & 222,000 & 24,000 & 0,02 & 1,92 \\
\hline 3 & $\begin{array}{c}\text { SDG } \\
18\end{array}$ & 10,392 & $9.611,186$ & 9,611 & 448,000 & 129,000 & 0,03 & 1,41 \\
\hline 4 & $\begin{array}{c}\text { SDG } \\
18 b\end{array}$ & 1,548 & $2.223,844$ & 2,224 & 198,000 & 64,000 & 0,06 & 0,36 \\
\hline 5 & $\begin{array}{l}\text { SDG } \\
19\end{array}$ & 0,796 & $1.190,684$ & 1,191 & 148,000 & 58,000 & 0,08 & 0,21 \\
\hline & & & & Total & & & & 4,10 \\
\hline
\end{tabular}

\begin{tabular}{cccccccc} 
CH & Bobot & \multicolumn{6}{c}{ CH Harian Kala Ulang $(\mathrm{mm})$} \\
$\mathrm{Jam}$ & & 2 th & 5 th & 10 th & 20 th & 50 th & 100 th \\
$\mathrm{Ke}$ & & 77,00 & 104,00 & 121,00 & 139,00 & 161,00 & 177,00 \\
1 & $12,32 \%$ & 9,48 & 12,81 & 14,90 & 17,12 & 19,83 & 21,80 \\
2 & $49,90 \%$ & 38,42 & 51,89 & 60,37 & 69,35 & 80,33 & 88,32 \\
3 & $24,22 \%$ & 18,65 & 25,19 & 29,30 & 33,66 & 38,99 & 42,86 \\
4 & $13,57 \%$ & 10,45 & 14,11 & 16,42 & 18,86 & 21,85 & 24,02
\end{tabular}

\section{Lokasi Banjir yang Diamati}

Pada penelitian ini mengamati debit banjir kala ulang 100 tahun (Q100) pada titiktitik lokasi banjir yang digambarkan pada Gambar 1. Berikut penjabarannya:

1. Junction-34 adalah lokasi banjir 1 (Perumahan Dinar Indah).

2. Junction-35 adalah lokasi banjir 2 (jalan raya depan Kubota).

3. Junction-38 adalah lokasi banjir 3 (Taman Tirto Agung).

4. Junction-39 adalah lokasi banjir 4 (Jl. Durian).

5. Junction-41 adalah lokasi banjir 5 (Simpang UNPAND)
6. Junction-42 adalah lokasi banjir 5 (Simpang UNPAND).

7. Junction-58 adalah Bendung Pucang Gading yang merupakan lokasi paling hilir pada penelitian ini.

Pemodelan banjir DAS Pucang Gading di software HEC-HMS ditampilkan pada Gambar 6.

Pengaruh embung, kolam dan sudetan rencana terhadap masing-masing skema ditampilkan pada Tabel 6. Hasil analisis banjir 3 skema pada penelitian di tampilkan pada Tabel 7 dan Tabel 8 adalah reduksi debit banjirnya.

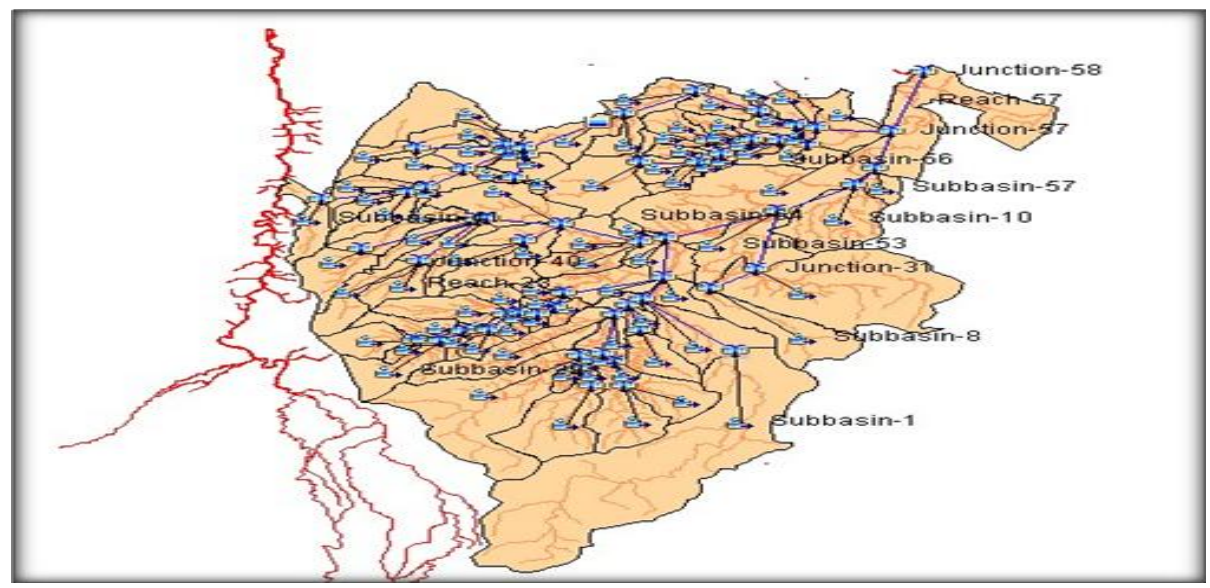

Gambar 6. Pemodelan banjir DAS Pucang Gading di software HEC-HMS. 
Tabel 6. Pengaruh pemodelan embung, kolam dan sudetan rencana pada masing-masing skema.

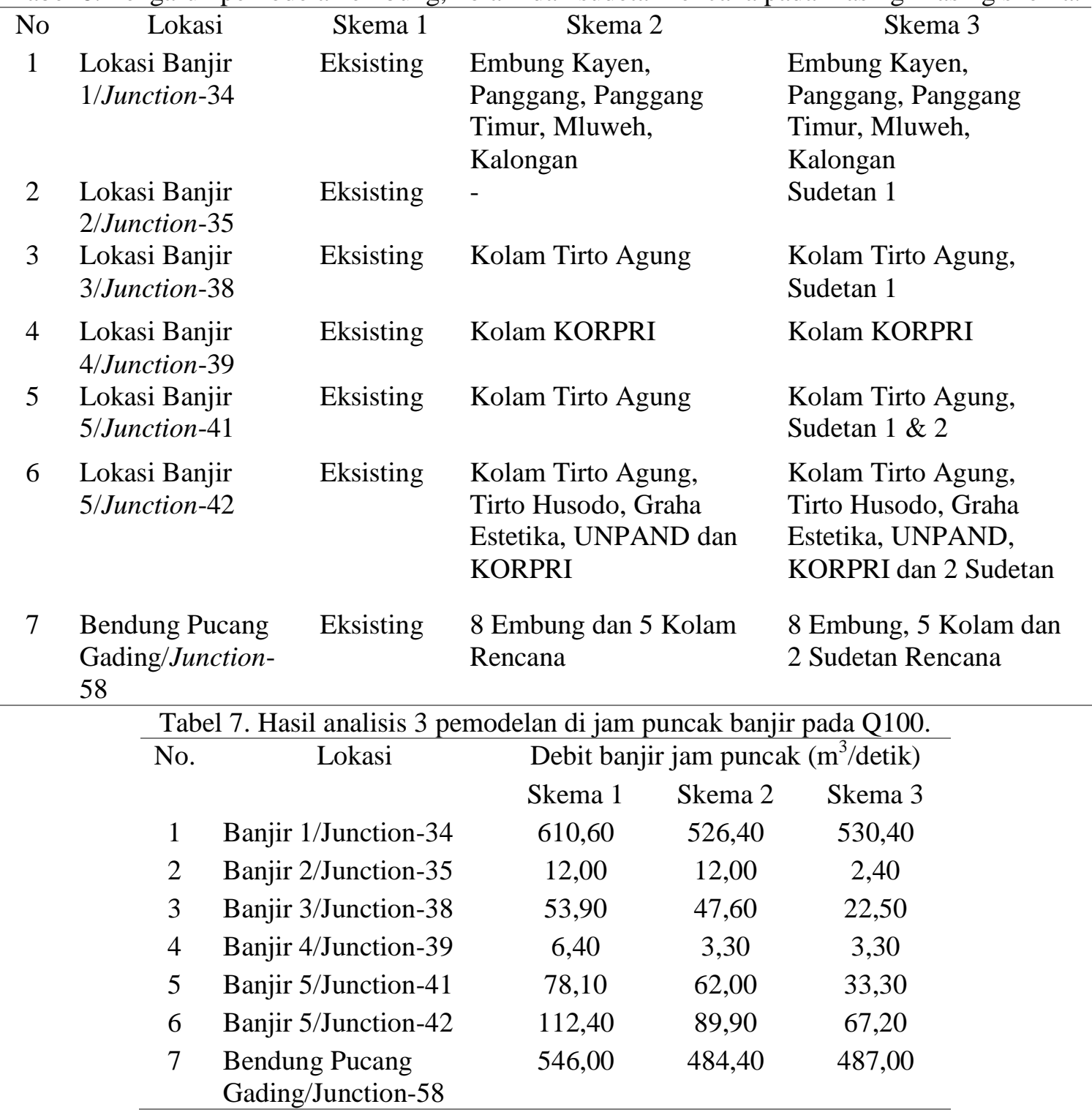

Tabel 8. Jumlah debit banjir yang direduksi.

\begin{tabular}{llcccc} 
No. & Lokasi & \multicolumn{3}{c}{ Reduksi debit banjir jam puncak } \\
& & $\begin{array}{c}\text { Skema 2 } \\
\left(\mathrm{m}^{3} / \text { detik }\right)\end{array}$ & $\begin{array}{c}\text { Skema 2 } \\
(\%)\end{array}$ & $\begin{array}{c}\text { Skema 3 } \\
\left(\mathrm{m}^{3} / \text { detik }\right)\end{array}$ & $\begin{array}{c}\text { Skema 3 } \\
(\%)\end{array}$ \\
& & & & & \\
& & & & & \\
1 & Banjir 1/Junction-34 & 84,20 & 13,79 & 80,20 & 13,13 \\
2 & Banjir 2/Junction-35 & 0,00 & 0,00 & 9,60 & 80,00 \\
3 & Banjir 3/Junction-38 & 6,30 & 11,69 & 31,40 & 58,26 \\
4 & Banjir 4/Junction-39 & 3,10 & 48,44 & 3,10 & 48,44 \\
5 & Banjir 5/Junction-41 & 16,10 & 20,61 & 44,80 & 57,36 \\
6 & Banjir 5/Junction-42 & 22,50 & 20,02 & 45,20 & 40,21 \\
7 & Bendung Pucang & 61,60 & 11,28 & 59,00 & 10,81 \\
& Gading/Junction-58 & & & & \\
\hline
\end{tabular}




\section{Pemilihan Alternatif}

Berdasarkan dari seluruh hasil analisis yang sudah dilakukan pada penelitian ini, maka dapat dipilih alternatifpemodelan yang direkomedasikan yaitu yang paling maksimal dalam mereduksi debit banjir puncak di masing-masing lokasi, berikut pembahasannya:

1. Pemilihan alternatif yang direkomendasikan di lokasi banjir 1 (Perumahan Dinar Indah) adalah 5 Embung (Kayen, Panggang, Panggang Timur, Mluweh dan Kalongan)yangmereduksi $84,20 \mathrm{~m}^{3} /$ detik $(13,79 \%)$ dibanding kondisi eksisting.

2. Pemilihan alternatif yang direkomendasikan di lokasi banjir 2 (Jalan raya depan Kubota) adalah Sudetan 1yangmereduksi $9,60 \mathrm{~m}^{3} /$ detik $(80,00 \%)$ dibanding kondisi eksisting.

3. Pemilihan alternatif yang direkomendasikan di lokasi banjir 3(Taman Tirto Agung) adalah Sudetan 1 dan Kolam Tirto Agungyangmereduksi $31,40 \mathrm{~m}^{3} /$ detik $(58,26 \%)$ dibanding kondisi eksisting.

4. Pemilihan alternatif yang direkomendasikan di lokasi banjir 4 (Jl. Durian) adalah Kolam KORPRI yang mereduksi sebesar $3,10 \mathrm{~m}^{3} /$ detik $(48,44 \%)$ dibanding kondisi eksisting.

5. Pemilihan alternatif yang direkomendasikan di lokasi banjir 5/ Junction-41 (simpang UNPAND) adalah Sudetan 1, 2, Kolam Tirto Agung dan Tirto Husodoyang mereduksi 44,80 m3/detik $(57,36 \%)$ dibanding kondisi eksisting.

6. Pemilihan alternatif yang direkomendasikan di lokasi banjir 5/ Junction-42 (simpang UNPAND) adalah 2 sudetan dan 4 Kolam (Tirto Agung, Tirto Husodo, Graha Estetika dan UNPAND)yang mereduksi 45,20 m3/detik $(40,21 \%)$ dibanding kondisi eksisting.

7. Pemilihan alternatif yang direkomendasikan di Bendung Pucang Gading adalah 8 Embung dan 5 Kolamyang mereduksi $45,20 \quad \mathrm{~m} 3 /$ detik $\quad(40,21 \%)$ dibanding kondisi eksisting.

\section{PENUTUP}

Berdasarkan pada analisis-analisis yang sudah dilakukan pada penelitian ini maka skema 2 direkomendasikan untuk lokasi banjir 1 (Perumahan Dinar Indah, reduksi sebesar
13,79\%), lokasi banjir 4 (Jl. Durian, reduksi sebesar 48,44\%) dan lokasi Bendung Pucang Gading (reduksi sebesar 40,21\%). Sedangkan skema 3 direkomendasikan untuk lokasi banjir 2 (jalan raya depan Kubota, reduksi sebesar 80\%), lokasi banjir 3 (Taman Tirto Agung, reduksi sebesar 58,26) dan lokasi banjir 5 (Simpang UNPAND reduksi sebesar 57,36\% dan 45,20\%). Rekomendasi tersebut adalah berdasar pada hasil reduksi paling maksimal.

\section{UCAPAN TERIMAKASIH}

Penulis mengucapkan terimakasih

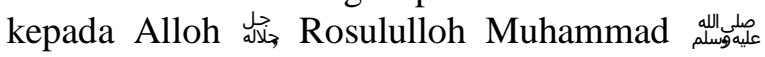
Pusat Penelitian Fakultas Teknik UNDIP, para Dosen yang telah membimbing, teman-teman yang telah memberikan saran serta referensi dan banyak pihak yang telah membantu dalam penelitian yang tidak dapat disebutkan satu persatu.

\section{DAFTAR PUSTAKA}

Andriawati, I. D., Rispiningtati. Juwono, P.T. (2015). Fektifitas Kegiatan Pengerukan Sedimen Waduk Wonogiri Ditinjau dari Nilai Ekonomi. Jurnal Teknik Pengairan. 6 (1), (55-65).

Laporan Akhir. (2019). Kajian Pengelolaan SDA Wilayah Timur. CV. Mitra Muda Rekayasa.

Limantara, L.M.(2015). Rekayasa Hidrologi. Yogyakarta:Andi.

Rachman, R.A., Suhardjono, Juwono, P.T., (2014). Studi Pengendalian Banjir di Kecamatan Kepanjen dengan Sumur Resapan. Jurnal Teknik Pengairan. 5 (1), 79-90.

Susilowati, Pratama, L.A., Kurniani, D., Darsono, S. (2014). Perancangan Check Dam Pramuka untuk Mengatasi Sedimentasi di Banjir Kanal Barat Kota Semarang. Jurnal Karya Teknik Sipil. 3 (1), 194-202.

Triatmodjo, B, (2009). Hidrologi Terapan. Yogyakarta. Andi.

Yudi, R.K., Nugroho, A. M., Darsono, S., Wulandari, D.A. (2017). Perencanaan Sistem Polder Wilayah Semarang Timur. Jurnal Karya Teknik Sipil. 6 (2), 265-275. 